\title{
O Direito Moral Após a Morte do Autor
}

\author{
Prof. Antônio Chaves \\ Ex-diretor e professor de Direito Civil da \\ Faculdade de Direito da USP
}

\section{S U M A R I O}

1 - Proteção da integridade das obras caídas em domínio público. Adaptações.

2 - Direitos morais que se transmitem aos herdeiros do Autor. A quem compete o seu exercicio. O executor testamentário.

3 - Herdeiros até o segundo grau, cônjuge, legatários e cessionários.

4 - Organismos profissionais. Defesa pelo Estado.

5 - Obras derivadas das que caíram no dominio público.

6 - Conflitos de interesses morais.

7 - Necessidade de sanções.

8 - Discussão da matéria no âmbito internacional. A contribuição da UNESCO.

\section{Proteção da integridade das obras caídas em domínio público. Adaptações.}

O estudo da matéria revela duas tendências opostas: de um lado, a preocupação de manter intacta a obra original, evitando manipulações, mutilações e alterações que lhe deturpem a essência que empresários inescrupulosos não hesitariam em introduzir, dificultando seu controle, e, de outro, as necessidades imperiosas decorrentes da evolução dos tempos.

Lembra V. DOZORTSEV que a forma primitiva, autêntica e original não é sempre a melhor para promover uma ampla difusão dos bens culturais. A elevação dos níveis de cultura desenvolveu o gosto das obras clássicas, muitas das quais são procuradas sob uma forma mais simplificada e moderna: o respeito absoluto e incondicional da integridade das obras pode sob esse aspecto resultar prejudicial à sociedade.

Cumpre distinguir entre os utilizadores cuja atividade orienta-se no sentido da difusão dos bens culturais, dos que recorrem a meios prejudiciais ao patrimônio cultural para realizar proveitos. Medidas visando proteger a integridade das obras sobre as quais o direito de autor extinguiu-se ajudarão mesmo os primeiros a se defenderem contra a concorrência dos segundos. 
«Se a intenção e o sistema de representação da obra são respeitados, conviria considerar como lícitas certas formas de intrusão na versão autêntica e original da obra, o acréscimo, por exemplo, de um prefácio ou de um posfácio, notas, ilustrações, etc., a tradução da obra numa outra língua, a utilização da obra sob uma forma condensada ou sob forma de extratos. São igualmente lícitas certas modificações da obra - adaptação, simplificação, tradução numa outra língua, incluída de uma língua antiga na língua moderna, transposição da obra num outro gênero (o fato, por exemplo, de levar um romance ao écran)

Por outro lado, parece que a percepção da obra será alterada se for permitido proceder a acréscimos, e em particular a modificações, isto é, a substituição de determinados elementos da obra por outros. E é absolutamente ilícito criar, a partir de uma obra clássica, uma obra inteiramente diferente do original pela intenção, o sistema diferente do original pela intenção, o sistema de representação, etc.

$\hat{E}$ portanto lícito o arranjo de seu remanejamento, mas não sua transformação, quando ela vem a criar uma obra total ou parcialmente nova. Certo, é possível criar uma obra nova independente utilizando alguns elementos de uma obra que não é mais protegida no quadro do direito de autor (assim como de uma obra que o é). Mas a obra nova deve ser nitidamente destacada da fonte de onde ela retira sua inspiração.

Além disso, é necessário que o arranjo seja claramente reconhecido quando do aproveitamento da obra para que se possa fazer imediatamente a distinção entre a obra original autêntica em toda a sua integridade e a obra arranjada.»

Preocupado em preservar a autenticidade das obras caídas em domínio público, o então Ministro de Estado da Educação e Cultura, JARBAS G. PASSARINHO, encaminhou ao Congresso Nacional projeto de lei, que tomou o $\mathrm{n}^{9} 716$ de 1972, propondo normas destinadas a preservar-lhes a fidelidade do texto, quando reeditadas.

Na Exposição de Motivos que o acompanhou, datada de 26-4-1972 (Diário do Congresso Nacional, Seção I, de 15-6-1972, pág. 1.787, e Seção II, 12-8-1972, págs. 2.170/1), encarece:

«... os arts. 763 e 672 do Código Civil, ao estabelecerem, respectivamente, o registro na Biblioteca Nacional dos trabalhos literários editados ou reproduzidos por qualquer sistetema de apreensão dos exemplares de obras publicadas fraudulentamente, deixam bem claro o propósito de proteger a propriedade intelectual. Ora, se cabe ao Poder Público defender o direito do autor, e a autenticidade do texto da 
obra ainda sob o domínio particular, terá forçosamente, e com muita razão, de resguardar aquelas que vencendo o tempo se consagram pela permanência do interesse de uma geração após outra.

O que tem verificado o Ministério nesse campo é que essas obras, após sucessivas e quase sempre descuidadas edições, apresentam grande desfiguração, quando confrontadas com o trabalho original. Foi o caso, para exemplificar, do romance Senhora, de JOSE DE ALENCAR, que, em recente reapresentação, além de frases truncadas pela supressão dos objetivos característicos do estilo do autor, sofrera, nas citações dos personagens, a conversão do «mil réis» em centavos do cruzeiro novo.

A medida ora proposta visa, pois, a coibir abusos semelhantes, de modo a assegurar a preservação de nosso patrimônio cultural».

O projeto foi convertido na Lei $\mathrm{n}^{\circ} 5.805$, de 3-10-1972, que estabelece normas destinadas a preservar a autenticidade das obras literárias caídas em domínio público, determinando:

«Art. 10 - As editoras sediadas no território nacional são obrigadas a adotar os textos fixados ou que tenham a fixação reconhecida pelo Instituto Nacional do Livro, quando editarem obras da literatura brasileira caídas em domínio público.

Parágrafo Único - A fixação de um texto consiste no estabelecimento do texto original, após o cotejo de várias edições de uma obra.

Art. $2^{\circ}$ - A edição de condensação, adaptações ou outras quaisquer formas de popularização dessas obras dependerá de assentimento prévio do Instituto Nacional do Livro.

Art. 3 - O Instituto Nacional do Livro publicará, periodicamente, no Diário Oficial da União, a relação dos textos fixados ou reconhecidos, promovendo, ao mesmo tempo, sua mais ampla divulgação.

Art. $4^{\circ}$ - O Instituto Nacional do Livro fará arquivar, de modo a permitir aos interessados a consulta no local, os relatórios que contenham as justificativas filológicas da fixação de cada texto, bem como os exemplares autênticos dos textos reconhecidos.

Art. $5^{\circ}-\mathrm{A}$ autoridade policial competente, por solicitação do Instituto Nacional do Livro, apreenderá os exemplares das obras de que trata esta Lei, editadas em desacordo com os textos fixados ou reconhecidos». 
2. Direitos morais que se transmitem aos herdeiros do autor. A quem compete o seu exercício. O executor testamentário.

Por morte do autor, - dispõe o $\S 1^{\circ}$ do art. 25 da Lei $n^{\circ} 5.988$, - transmitem-se aos seus herdeiros os direitos a que se referem os incisos I a IV do mesmo dispositivo, isto é, dentre os seis direitos morais que enumera, exclui apenas o de modificar a obra e o de retirá-la da circulação ou de lhe suspender qualquer forma de utilização já autorizada.

Uma legislação ciosa do patrimônio intelectual de seus jurisdicionado $_{S}$ - encarece HENRI DESBOIS - deve proteger o direito moral post-mortem, de maneira a garantir a proteção das obras sem a vontade ou mesmo contra a vontade dos herdeiros ou cessionários. «Porque a personalidade do autor sobrevive através da obra que é a sua emanação. Para realizar a sua proteção é portanto necessário manter o direito moral e adaptá-lo à sua missão «póstuma».

Os atributos do direito moral de comunicação ao público, de arrependimento ou de modificação não podem, evidentemente, acrescenta - sobreviver intactos ao autor, uma vez que implicam numa mudança de vontade que, somente o criador teria podido manifestar. Os que sobrevivem a ele não agirão jamais a não ser no sentido das suas intenções, como servidores, não como donos; não poderão tomar iniciativa de um retoque que teria por efeito violar, não executar as decisões do defunto.

As prerrogativas do direito moral, de respeito e de paternidade subsistem, ao contrário, depois da morte, a fim de garantir a preservação da obra contra tentativas de alteração, de má utilização ou de supressão no nome do autor.

Da mesma forma constitui dever dos sucessores proibir a comunicação ao público de inéditos de que o escritor entendia conservar o segredo, em particular das cartas e missivas que ele queria subtrair à publicidade.

A lei francesa de 11-03-1957 reconhece, art. 19, cabe depois da morte do autor, o exercício do direito de divulgação das obras póstumas, aos seus herdeiros, durante a vida dos mesmos, pelo ou pelos executores testamentários designados pelo autor. Em sua falta, ou após a sua morte, e salvo disposição contrária do autor, este direito é exercido na ordem seguinte: pelos descendentes, pelo cônjuge contra o qual não existe julgamento com força de coisa julgada de separação de corpos ou que não tenha contraído um novo casamento, por herdeiros outros além dos descendentes, que recolhem toda ou parte da sucessão e pelos legatários universais ou donatários da universalidade dos bens futuros.

Este direito pode exercer-se mesmo depois da expiração do direito exclusivo de aproveitamento determinado pelo art. 21. 
Em caso de abuso notório no uso ou no de não uso do direito de divulgação por parte dos representantes do autor falecido considerados no artigo anterior, o tribunal civil pode determinar qualquer medida apropriada. O mesmo ocorre se houver conflito entre os referidos representantes, se não há titular de direito conhecido ou em caso de vaga ou de deserdação.

O Tribunal pode ser provocado especialmente pelo Ministro encarregado das artes e das letras (art. 20).

Mas é em geral ao período posterior à queda da obra no domínio público e ao desaparecimento dos herdeiros que se pensa quando se fala de proteção das obras do domínio público, considerando as obras primas da literatura.

\section{Herdeiros até o segundo grau, cônjuge, legatários e cessionários.}

Limita-se nossa LDA a fazer referência aos herdeiros do autor. Quais sejam esses herdeiros, não são simplesmente, os indicados pelo CC: descendentes, ascendentes, cônjuge sobrevivente, colaterais, Estados, Distrito Federal, União (art. 1603), só deferida ao cônjuge se, ao tempo da morte do outro, não estava dissolvida a sociedade conjugal, à falta de ascendentes ou descendentes (1611 caput) e colaterais até o $4^{\circ}$ grau.

Essas regras têm que sofrer as adaptações decorrentes dos arts. 42 e segs. LDA, importando lembrar que o art. 47 só considera sucessores do autor seus herdeiros até o segundo grau na linha reta ou colateral, bem como o cônjuge, os legatários e cessionários.

Trata-se, bem de ver, de regras especiais, derrogatórias em parte do direito sucessório comum, e de caráter imperativo.

Embora não se refira a nossa lei expressamente ao executor testamentário não resta dúvida ser este a pessoa mais indicada para o cumprimento das determinações do autor falecido, que, em vida, tem inteira liberdade de escolha, motivadamente ou não.

A ele deve ser equiparada qualquer pessoa a quem, por escrito, independentemente de qualquer formalidade, tenha o criador da obra dado a incumbência de velar por ela.

Incumbir-lhe-á, seguindo rigorosamente as instruções que lhe tiverem sido ministradas, divulgar as obras póstumas, exercendo pois o direito de decidir se o momento é oportuno para fazê-lo, procurando sempre seguir as intenções do defunto, expressas ou a seu ver presumidas, e estabelecendo as cláusulas inerentes a cada contrato.

«E evidente - consigna JEAN MATTHYSSENS - «que o legislador almejou fazer exercer o direito pelos que estavam mais próximos do pensamento do autor, em primeiro lugar, pelo executor testamentário por ele designado. Se um autor considera que seus descen- 
dentes ou não têm afinidade com o seu pensamento e conseguintemente não estão qualificados para serem guardas de seus interesses espirituais, ou estão aproximados de seu pensamento mas não estão suficientemente armados para defender sua obra, tem toda faculdade para nomear um executor testamentário».

Trata-se de uma missão de fidelidade à memória do autor falecido, um dever, mais do que um direito. Recomenda porém que não considerem a obra como um santuário, proibindo sistematicamente qualquer mudança, mas que recusem as modificações que trairiam o próprio espírito da mesma.

«Este dever está ligado ao autor desaparecido e não aos interesses próprios dos herdeiros. Devem estes fazer abstração de suas opiniões políticas, religiosas, sociais, porque eles têm um dever de fidelidade à memória do defunto. Qualquer abuso no uso do direito seria não somente condenável no plano moral, mas objeto de sanção pelos tribunais. Constituiria também um abuso o não uso, na medida em que um herdeiro, mais preocupado em receber direitos do que velar pelos interesses espirituais do autor, aceitasse uma desfiguração da obra que ele deve servir. Este dever é de interesse geral, porque o público tem o direito de conhecer a obra tal como o autor a concedeu, a quis».

Considera inalienáveis e irrenunciáveis os direitos morais do autor o art. 28 da lei pátria.

A lei francesa consagra a perpetuidade, a inalienabilidade e a imprescritibilidade desse direito moral, estabelecendo que os herdeiros podem exercê-lo mesmo após a expiração do direito exclusivo de aproveitamento.

Estabelece o Delegado Geral da Société des Auteurs et Compositeurs Dramatiques oportuna distinção entre a caída da obra no domínio público enquanto existem herdeiros e a que ocorre depois do desaparecimento dos mesmos.

$\mathrm{Na}$ primeira hipótese, durante esse período, o direito moral será exercido no «estado puro»: não existe com efeito coexistência de um direito de autorizar ligado ao direito pecuniário e de um direito moral; o que existe é somente o direito moral. Qualquer obra pode, sem autorização dos herdeiros, ser comunicada ao público. Caso, porém, essa comunicação desnature a obra, poderão os herdeiros recorrer aos tribunais.

Anota que se a obra não caiu ainda no domínio público, os herdeiros preferem apoiar-se em seu direito de autorizar ou de proibir antes que sobre o direito moral: deixar que acabem as representações em curso, ainda que desnaturem a obra, mas recusar, em seguida, qualquer nova autorização. 
CHARLES AUSSY cita julgados franceses no sentido de que, em falta de executor testamentário ou de legatário, a viúva ou dos herdeiros do autor são qualificados para velar pela reprodução fiel das suas obras.

Adita em seguida estarem todos de acordo em reconhecer à viúva e aos herdeiros a missão de proteger a obra contra qualquer alteração, e de exigir o respeito de sua assinatura, acrescentando ser para eles um dever e um culto para com a memória do autor desaparecido.

Pondera, ainda:

«O problema torna-se mais delicado quando estas mesmas pessoas, não se contentando em manter a obra intangível, pretendem, além disso, arrogar-se o direito de modificá-la ou mesmo de suprimí-la, sob o pretexto de que ela lhes pertence ou que eles têm idéias morais, intelectuais, politicas ou religiosas diferentes das do autor.»

Demonstra estar mal fundamentado semelhante ponto de vista, porque, de um lado, o direito de autor não constitui uma propriedade ordinária e porque, por outro lado, a ficção da continuação da pessoa do autor por seus herdeiros, admitida correntemente, aliás, sem necessidade, para a transmissão do patrimônio, é absolutamente injustificável do ponto de vista dos direitos morais:

«Tais direitos não são transmitidos aos herdeiros a não ser na medida em que eles têm por finalidade manter intacta a reputação do autor. Ora, este, enquanto vivo, foi o único juiz das suas opiniões e do valor artístico da sua obra. Em virtude da sua morte, ela adquiriu uma forma definitiva e pode-se afirmar que haveria profanação, por parte dos herdeiros não somente cessar a publicação, mas também em mudar o caráter e nela inserir especialmente doutrinas que, aos seus últimos momentos, o autor teria sempre reprovado. Agir por esta forma seria violar seu pensamento e levar o mal grave atentado à sua personalidade».

Exemplo a respeito da matéria é a disposição expressa do art. 24 da lei italiana.

\section{Organismos profissionais. Defesa pelo Estado.}

JEAN MATTHYSSENS aponta duas escolas no que diz respeito à defesa dos interesses espirituais: uma entendendo que na ausência dos herdeiros, impõe-se a liberdade. Mesmo entre os partidários desse ponto de vista, alguns entendem que pelo menos nas representações realizadas nos teatros oficiais deveriam as obras ser mostradas tais como o autor as concebeu.

Mas a maioria entende que, não havendo mais herdeiros, devem intervir os organismos profissionais, antes que as entidades públicas 
ou o Estado. Na França, o Centro das Letras tem sido designado para velar pelo respeito da integridade ou da substância das obras, mas, na prática, não se interessou por esta missão de guarda do patrimônio literário francês.

«Assim», - conclui - «o direito moral não existe a não ser em seu princípio. Tem mesmo a primazia sobre o direito pecuniário e é o elemento essencial do direito de autor, mas não existe em seu exercício. Direito moral a direito pecuniário é um todo e é o direito de autor. Mas quando o direito de autor não pode ser exercido em sua totalidade, o elemento moral permanece teórico, mesmo se o legislador afirma a sua perpetuidade. É necessário fazê-lo viver para proteger nosso patrimônio cultural, tão ameaçado como os nossos monumentos históricos».

Atribui o $\S 2^{\circ}$ do art. 25 da lei pátria ao Estado, que a exercerá através do Conselho Nacional de Direito Autoral, a defesa da integridade e genuinidade da obra caída em domínio público.

Diante do repúdio a qualquer forma de «autorização» por parte do Estado para o aproveitamento das obras caídas em domínio público, visto que unicamente o titular do direito é que poderá fazer concessões dessa natureza, inclusive no que diz respeito a eventuais adaptações e modificações da sua obra, com o falecimento deste, quem zelará pela sua preservação - conveniência, do ponto de vista individual, mas verdadeira necessidade social de preservar os tesouros literários, artísticos e científicos que nos foram legados pelas gerações passadas?

Somente um regime de proteção administrativa «a posteriori» poderá ser considerado, mesmo no que diz respeito às modificações a que sejam submetidas essas obras.

Eliminada a concessão estatal, terão então os interessados ampla liberdade de ação, incorrendo porém nos riscos decorrentes de eventuais abusos, ao introduzirem modificações atentatórias ao «espírito» da obra caída no domínio comum.

O art. 120 da lei colombiana de 28-01-1982 inclui entre as atribuições das associações de autores, "velar pela salvaguarda da tradição intelectual e artística nacional.»

É uma belíssima frase - ressalta ARCADIO PLAZAS - de um conteúdo transcendente, que talvez possa responder como função essencial não só a essas associações, como a muitas outras instituições públicas e privadas, vinculadas a tão altos ideais.

«Mas, chegando um pouco mais à realidade da lei e dos direitos que nela se consagram, prefiriria que nesse item se atribuísse às mencionadas associações ou sociedades a função essencial de salvaguardar os direitos morais dos autores e dos artistas intérpretes e executantes cujas obras tenham caído no domínio público ou que por descuido da- 
queles se utilizam, com tanta freqüência, para fins comerciais e publicitários de pouca importância sem mencionar o nome de seus autores ou o título das obras modificando-as caprichosamente em forma que prejudica o prestígio dos autores.»

Entre nós, o produto domínio público remunerado era administrado pelo CNDA, através do Fundo de Direito Autoral-FDA.

Revogados, no entanto, o art. 93 e o item I do art. 120 LDA relativos à utilização das obras caídas no domínio público, a quem compete semelhante fiscalização, no caso do desinteresse ou da ausência de iniciativa dos herdeiros diretos? Ninguém melhor do que o próprio Estado, no caso através do CNDA poderia ter atribuições nesse sentido.

A Lei 5.805 deu ao Instituto Nacional do Livro competência para dar seu «assentimento prévio» à edição de condensação, adaptações ou outras quaisquer formas de popularização de obras da literatura brasileira caídas em domínio público.

Mas não há razão que justifique ficarem tais medidas de proteção limitadas às obras impressas, e, muito menos, exclusivamente às nacionais.

Ao atribuir zo próprio Estado, através do Conselho Nacional de Direito Autoral, competência para a defesa da integridade e genuidade da obra caída em domínio público (art. $25, \S 2^{\circ}$ ), a Lei 5.988 deu um passo diante.

\section{Obras derivadas das que caíram no domínio público.}

Problema dos mais delicados é o das obras derivadas daquelas que caíram no domínio público.

Pretender que estas sejam conservadas sempre em sua forma originária, reeditando-as ou dando-lhes qualquer forma de comunicação tal qual forma concebidas decorridos às vezes muitos séculos, apresenta um interesse limitado ao estreito círculo de uma elite de estudiosos: seriam inintelegíveis ou indigestas para o público em geral, que tem até aversão pelo termo de obras «clássicas».

Não admitir que sofram qualquer forma de modernização, mediante adaptações ou condensações, às vezes com eliminação de largas descrições ou digressões, ou mesmo de fatos ou episódios que podem ser dispensados, seria privar a coletividade do conhecimento de elaborações que no entanto constituem a própria essência do patrimônio cultural da humanidade.

Como conciliar esse interesse na divulgação com o da preservação dos caracteres essenciais dessas obras-primas? 
V. DOZORTSEV enumera os múltiplos fatores que contribuem para essa situação: elevação do nível de cultura da população, preparação insuficiente de amplas camadas a se apropriarem destas fontes em seu aspecto original: tendência a explorar esse interesse pelos clássicos a fim de promover obras ou produtos neles inspirados; inclinação dos empresários para utilizar esse interesse para fins comerciais e lucrativos, tanto mais que com menores despesas quando não protegidas pelo direito de autor; desenvolvimento dos diversos meios técnicos de reprodução, fenômeno particularmente manifestado nos casos de obras musicais.

«A difusão de obras que não são mais protegidas, sob uma forma não original, tomou tal amplitude que risca de fazer esquecer ao público a obra original autêntica. Ela coloca em perigo igualmente um patrimônio intelectual da mais alta importância que constitui a base da cultura nacional. Esta situação levantou sérias preocupações não somente no plano nacional, mas em escala internacional. O problema naturalmente chamou a atenção da UNESCO, cujos fins fundamentais, nos termos do art. $1^{\circ}$ de seu Ato constitutivo, é de velar «pela conservação e pela proteção do patrimônio universal de livros, de obras de arte e de outros monumentos de interesse histórico ou científico».

Evoca as várias iniciativas que a UNESCO tomou objetivando estudos sobre o respeito à integridade das obras pertencentes ao domínio público e focaliza a matéria sob o ponto de vista do interesse dos consumidores, como tais entendidas as pessoas que se encarregam da reprodução e da difusão das obras - editores e produtores de fonogramas e de videogramas.

Sustenta - tese com a qual não concordamos - não haver razão para considerar essa proteção como parcela do direito de autor e propõe - tarefa que consideramos impossível de realizar satisfatoriamente - «selecionar as obras que façam parte do patrimônio cultural, do tesouro da cultura nacional, apresentando um interesse para a coletividade», a fim de submeter sua integridade a um controle especial.

A única solução possível, a nosso ver, é transigir com as exigências inicialmente indicadas, reconhecendo, com o professor do Instituto de Pesquisa da URSS sobre a legislação soviética, que a utilidade da proteção à integridade dessas obras pode ser avaliadas de diferentes pontos de vista.

$\mathrm{O}$ interesse do utilizador é satisfazer às exigências sociais, que depende de diversos fatores, mas sobre a formação da qual ele exerce uma influência certa. "Uma ampla difusão dos bens culturais reproduzidos pelo utilizador é uma condição indispensável da eficácia da empresa comercial, isto é, do interesse que é o motor da sua atividade. A esse respeito, os interesses da sociedade coincidem com os dos utili- 
zadores igualmente interessados na conservação do patrimônio cultural, em sua difusão em sua assimilação pela consciência popular.»

O ponto fundamental da exposição do especialista é o que diz respeito ao conteúdo totalmente diferente que apresenta a integridade da obra que deixou de beneficiar da proteção do direito de autor raquela que a caracteriza nesse quadro.

«A proteção responde aqui a um outro cuidado, o de transmitir à coletividade a herança cultural das gerações anteriores.

Diferentemente da regra aplicável no quadro do direito de autor, conviria estabelecer o princípio da liceidade da exploração, sob uma forma modificada, das obras que não são mais protegidas pelo direito de autor. Todavia, estas modificações devem satisfazer a uma condição geral: a preservação da integridade da obra exige a da intenção, do sistema de representação e dos outros meios artísticos com a ajuda dos quais esta intenção deve e fazer sentir, porque é necessário, em princípio, que a obra modificada seja percebida exatamente como a obra original».

Realça, finalmente, a importância de formular com precisão os critérios aos quais devem satisfazer, para serem lícitos, os afastamentos com relação à obra autêntica.

Qual será, entre nós, a autoridade competente para pronunciar-se a respeito de tão delicada matéria?

Não se pode ser outra senão o CNDA, órgão não só de fiscalização, como de «consulta e assistência», art. 116 LDA.

Dentro dessas atribuições de consulta poderia mesmo - uma vez que já funciona como árbitro em questões que versem sobre direitos autorais nos casos especificados no item $V$ do art. 117, ser consultado pelos interessados antes de procederem as dispendiosas formas de divulgação de obras adaptadas, não se confundindo, entretanto, a resposta a essas consultas com a execrada «autorização» revogada do art. 93.

Responderá cada qual pelos excessos e abusos que venha a cometer, violando o direito moral das obras caídas em domínio público.

Tanto Victor Lima Barreto como Carlos Alberto de Souza Barros, pretendendo adaptar para o cinema o romance Inocência, de Alfredo D'Escragnolle Taunay (Visconde de Taunay) solicitaram o devido registro à Embrafilme.

Esta encaminhou consulta ao CNDA para saber a quem caberiam os direitos autorais da adaptação para o cinema, e se poderia haver dois roteiros de autores diferentes para a mesma obra. 
A decisão coube à $1^{\text {a }}$ Câmara do CNDA, que em agosto de 1980 firmou o ponto de vista de que:

«em se tratando de adaptação de obra caída em domínio público, a obra derivada (o roteiro cinematográfico) pode ser elaborada independentemente, de autorização de quem quer que seja. Contudo, a sua utilização dependerá de autorização do Conselho Nacional de Direito Autoral».

Assim, por se tratar de obra caída em domínio comum, sua adaptação pode ser feita livremente e os roteiros registrados na Embrafilme, mas a utilização de qualquer deles dependerá, sempre de autorização do CNDA, posto que, no Brasil, em face da Lei n 5.988/73, o domínio público está sob o controle desse órgão. Quando não se tratar de adaptação o produto oriundo do Direito Autoral se destina ao Fundo de Direito Autoral. Na adaptação cinematográfica, porém, o direito de autor incide sobre o roteiro que for aproveitado. Aliás, no caso de «Inocência», além dos roteiros de Victor Lima Barreto e de Carlos Alberto de Souza Barros, há um terceiro que, entretanto, não foi objeto da consulta da Embrafilme.

\section{Conflitos de Interesses Morais.}

Nem sempre aquela presunção de que os herdeiros e sucessores do autor sejam as pessoas mais indicadas para velar pelo resguardo da integridade e genuidade da obra resulta verdadeiro.

São bastante numerosos os casos em que não manifestam a necessária isenção de ânimo, ou superioridade intelectual indispensável para dar fiel cumprimento às intenções do criador da obra, não faltando mesmo os que vejam aí uma oportunidade para dar vazão a sentimentos de hostilidade, de desrespeito, ou simplesmente concedam primazia às suas preferências, nem sempre em harmonia com a intenção do falecido.

Encarece a propósito HENRI DESBOIS; à pág. 646 de sua obra que uma legislação ciosa do patrimônio intelectual dos seus jurisdicionados deve proteger o direito moral post-mortem, de maneira a garantir a proteção das obras sem a vontade ou mesmo contra a vontade dos herdeiros ou cessionários. «Porque a personalidade de autor sobrevive através da obra que é a sua emanação. Para realizar a sua proteção é portanto necessário manter o direito moral e adaptá-lo à sua missão «póstuma».

Permite, por isso, o art. 20 da lei francesa chamar ao cumprimento de seus deveres os titulares infiéis. O Tribunal pode tomar «qualquer medida apropriada», isto é, ordenar a publicação que o autor tinha determinado fosse efetuada após sua morte, por termo a que ele havia proibido, opor-se às iniciativas que desnaturam a obra e, nos casos desesperados, retirar dos maus guardas a missão que lhes havia sido confiada. 
As dificuldades que tão freqüentemente ocorrem em matéria de partilha dos bens materiais são muito maiores e mais delicadas de resolver quando surgem conflitos relativos ao direito moral de autor.

Serão, por prioridade, - observa ROBERT PLAISANT - executores testamentários os que dispõem do direito de divulgar a obra sem poder se apropriar do respectivo produto. Caso o autor não tenha regulamentado, por meio de testamento, as relações entre o direito moral e o direito pecuniário, não parece indispensável que as decisões tomadas pelos executores testamentários, quanto a publicação da obra, sejam aprovadas pelos herdeiros, investidos dos direitos pecuniários, salvo, em hipótese de desacordo, decisão dos tribunais.

Os direitos pecuniários, simples elementos do patrimônio, são submetidos às regras do direito comum, nada impedindo que sendo vários os herdeiros, os partilhem como bem entenderem.

Entre nós, muita gente se incomoda com a letra, nada mais nada menos, do Hino Nacional. $\overline{\mathrm{E}}$ o «deitado eternamente» que causa vexame.

Foi proposto substituí-lo por «firmado». Será que ficar firmado num berço, por esplêndido seja, - eternamente - será o ideal de um povo?

Mas o que interessa não é a solução lingüistica ou métrica e sim a jurídica.

Analisando os dispositivos legais pertinentes sustenta J. PEREIRA o HINO E o DIREITo do AUTOR, o Estado de São Paulo de 13-12-1981 que não pode ser feita a alteração dos versos de Osório Duque de Estrada sem o consentimento dos herdeiros, não só do autor dos versos, como da própria música, visto que também os de Francisco Manuel da Silva tem sobre a composição o direito moral que faz com que a obra permaneça ligada aos seus autores perpetuamente, e mantida a sua integridade.

Sem essa permissão, não poderia o Estado proceder a quaisquer modificações, inclusive a reducão dos versos, como também já se propõs com alguma procedência.

Mas a verdade é que nem mesmo com a concordância de todos os herdeiros poderá ser legalmente modificada a letra do Hino Nacional.

A questão do consentimento dos herdeiros ou legatários em modificar a obra, - acentua ROBERT PLAISANT - é das mais delicadas. Se, de um lado, não existe uma disposição legal recusando-lhes esse direito, de outro lado, autorizá-los a modificar ou fazer modificar a obra é chocante, em razão da contradição evidente que opõe esta faculdade ao caráter pessoal da obra, sobre a qual se funda todo o direito de autor. 
Considera necessário recusar aos herdeiros o direito de modificar, ou de permitir que se modifique a obra como ela se materializa num objeto corporal: pintura, escultura; o caráter estritamente pessoal da criação justifica esta solução. Quanto ao mais, julga necessário reconhecer aos herdeiros unânimes o direito de autorizar qualquer reprodução, representação, adaptação, comportando modificações da obra, por mais profundas que sejam.

MICHAÉLIDES-NOUAROS, sustenta que, além de aos cônjuges e descendentes, deve-se reconhecer a proteção do direito moral do autor falecido às organizações profissionais, que poderiam agir para a salvaguarda do direito moral no caso de negligência daqueles: elas poderiam mesmo verificar a maneira pela qual os herdeiros exercem o direito moral e opor-se a atos que constituam um descumprimento grave dos seus deveres.

«Depois da queda da obra no domínio público, somente as organizações profissionais são as melhores qualificadas para se encarregarem da defesa da integridade das obras; mas para esta finalidade elas deveriam organizar um serviço especial, que, em vista de sua utilidade social, teria direito ao apoio financeiro do Estado para preencher com êxito a sua missão».

Com relação às obras caídas em domínio público atribui o $\S 2^{\circ}$ ao Estado, através do CNDA a defesa da integridade e genuidade da obra.

Parece lógica a solução, visto que o art. 180 da Constituição Federal reconhece seu dever do Estado o amparo à cultura.

Uma vez que pelo seu parágrafo único ficam sob a proteção especial do Poder Público os documentos, as obras e os locais de valor histórico ou artístico, os monumentos e as paisagens naturais notáveis, bem como as jazidas arqueológicas, nada mais razoável que tal proteção alcance as obras e documentos de valor histórico não apenas sob o seu aspecto material, físico, mas também no que diz respeito ao seu conteúdo, pondo-as a salvo de manipulações inescrupulosas, uma vez cessada a vigilância do autor ou de seus familiares mais próximos.

\section{Necessidades de Sanções}

Como encarece JEAN VILBOIS, o domínio público remunerado, estando exposto a perigos em razão do seu próprio princípio - a liberdade de utilização das obras —, é necessário colocá-lo em boa ordem, a fim de que o pagamento da retribuição não fique eludido.

«Durante o período de direito exclusivo, o direito de autor fica sujeito a numerosas violações que uma fiscalização vigilante nem sempre consegue evitar. Durante o período do domínio público remunerado esta verificação deverá ser 
reforçada e as fraudes não serão previamente desencorajadas a não ser pelo estabelecimento de uma rede de sanções fáceis, enérgicas e eficazes. Deverão elas ser de duas ordens: preventivas e repressivas.

A proteção preventiva deve dispensar, se for bem organizada, recorrer à repressão, salvo em casos muito raros. Praticada na Itália, na Noruega, na Dinamarca e no Brasil, ela tem sido reclamada por agrupamentos de autores: sem ela, a proteção do direito de autor permanecerá sempre ilusória. Deveria ser admitida de uma maneira geral na lei: sua introdução na parte relativa ao domínio público remunerado prepararia talvez a adoção ulterior para todas as obras. É necessário, portanto, não hesitar em fazer a experiência se se apresentar a ocasião».

Lembrando que a proteção penal da paternidade intelectual, da identificação pelo título e da integridade das obras intelectuais do domínio privado não somente está prevista em atenção ao interesse privado e na instância privada, mas também em benefício dos valores coletivos, considera CARLOS MOUCHET que deveriam estender-se expressamente ao uso ilícito de obras em domínio público as sanções penais estabelecidas pelas hipóteses previstas na legislação comum.

\section{Discussão da matéria no âmbito internacional. A contribuição da UNESCO.}

No âmbito internacional a preocupação não é menor, como dedemonstra o fato de terem-se reunido, de 18 a 21-9-1979, os representantes de nove organizações internacionais não governamentais em Paris, na sede da UNESCO, num grupo de trabalho para examinar o direito ao respeito e à integridade das obras pertencentes ao domínio público.

«Reconhecendo que a noção de domínio público, eminentemente contingente e fluida's, - consigna a Revue Internacionale du Droit d' Auteur (n' 103, de janeiro de 1980, pág. 190) - implicava a possibilidade de utilizar uma obra do espírito sem autorização prévia e sem pagamento de retribuição, considerou o Grupo que não era menos indispensável garantir a salvaguarda dos interesses culturais do público e evitar que um prejuízo fosse causado à liberdade da obra original.

Considerando, nesse contexto, que a preservação das obras do espírito contra a destruição, bem como contra qualquer deformação que prejudicaria sua identidade como componente do patrimônio cultural das nações, deveria ser garantida, o Grupo de Trabalho foi unânime em considerar que duas categorias de medidas seriam de natureza a assegurar 
a preservação das obras do espírito, a salvaguarda dos interesses do público e a prevenção dos usos abusivos, a saber:

I - a adoção de disposições apropriadas, legislativas, regulamentadoras ou de qualquer natureza;

II - a designação de uma autoridade qualificada (pessoa física ou moral de direito privado ou de direito público) para agir a respeito».

Dando continuidade ao seu trabalho, a seção de direito de autor da UNESCO dirigiu, em data de 23-09-1980 aos seus membros uma carta circular, que lhes submetia um questionário, solicitando informações. Obteve 46 respostas, que foram objeto de estudo por parte de um comitê de peritos não governamentais, que se reuniu em Genebra de 26 a 30-04-1982.

Com base nessas informações, foram formuladas, nos dias 9 a 15-12-1982 «Observações» pelos peritos governamentais que se reuniram novamente, em comitê, de 17 a 21-01-1983.

A representante do Brasil, Segundo-Secretário ALMERINDA AUGUSTA DE FREITAS CARVALHO apresentou minucioso relatório.

Dentre as opiniões expressas pela maioria dos membros do Comitê, destaca:

- a necessidade de que se estabeleça uma legislacãa internacional destinada à proteção das obras caídas em domínio público, o que foi contestado apenas pelas delegações do Reino Unido, da Ãustria e dos países baixos;

- a totalidade das obras caídas em domínio público deveria ser protegida por normas nacionais e internacionais, uma vez que uma seleção de obras a serem protegidas

- por um comitê nacional ou internacional - acarretaria dificuldades como:

a determinação de um critério para seleção;

a emissão de juízo de valor sobre obras consagradas;

- a necessidade que sejam levadas em consideração obras que são «redescobertas» pelo público;

. o desconhecimento de obras de importância local e/ou regional.

Em alguns países, tal como a Finlândia, o Poder Público pode selecionar obras que, por seu interesse e valor cultural, devem ser objeto de especial proteção. 
«Uma recomendaç̃o aos Estados-Membros, e, portanto, de cunho apenas indicativo, seria o instrumento adequado à formalização das normas internacionais destinadas à proteção das obras em apreço.»

A este respeito foi aventada a hipótese de que se deveria ter como objetivo final dos trabalhos a assinatura de uma convenção. O Secretariado, consultado sobre a conveniência do instrumento, referiu-se à definição do Conselheiro Jurídico das Nações Unidas, pela «qual a Convenção é um instrumento formal e solene que se justifica em raras ocasiões, quando são enunciados princípios de grande importância e de valor durável», o que foi considerado demasiado formal, não correspondendo à flexibilidade requerida por matéria tão complexa.

«A expiração do prazo de proteção ao direito de autor e, portanto, o fato de que as obras do espirito caiam no domínio público, não deve ser considerado como licença para que as obras sejam desfiguradas.»

Nesse sentido analisa três aspectos da questão:

1 - com referência ao autor: preservação da paternidade da obra e de sua integridade, os «condensados», adaptações ou quaisquer outros tipos de modificação do original, deverão ser claramente indicados ao público;

2 - com relação ao público: preservação de seus direitos de livre acesso à informação e, sobretudo, à informação correta;

3 - sobre as futuras gerações: no sentido de que lhes seja resguardado o acesso a obras não deturpadas e que, através da mensagem cultural autêntica dos autores do passado, o patrimônio mundial seja protegido.

«A proteção dos bens de domínio público pode ser baseada na noção de «direito moral» dos autores, aos quais são geralmente atribuídas, pelo menos, duas prerrogativas: a paternidade da obra e o respeito à sua integridade. Esta postura foi considerada apropriada porque a noção de direito moral é reconhecida, nas legislações relativas a direitos autorais, na maioria dos Estados-Membros, sobretudo os que seguem a tradição do direito romano. A perpetuidade dos direitos morais do autor é outra característica desta corrente.

Já no contexto dos países que se baseiam no direito anglo-saxão, geralmente predomina a noção de que os direitos morais do autor têm a mesmo duração da proteção pecuniária que é assegurada a seus herdeiros (de 25 a 50 anos após a morte do autor). Há, ainda, países em cuja 
legislação não aparece a figura jurídica do «direito moral». Nestes países podem ser aplicadas regras com regras como se referem ao direito de responsabilidade civil, à teoria geral do abuso do direito, à «equity», ao direito dos consumidores, à da preservação dos monumentos etc.»

«Cabe aos legisladores nacionais instituir uma proteção adequada das obras de domínio público, a nível nacional, baseando-se nas leis, costumes e tradições de cada Estado. A Cooperação entre os Estados-Membros sobre a proteção das obras de domínio público foi também considerada importante e necessária pelos membros do Comitê.»

As delegações do Reino Unido, Ãustria e Países baixos, apesar de terem compartilhado da preocupação geral quanto ao risco de deturpação da autenticidade das obras caídas em domínio público, consideraram que não seria necessária uma regulamentação internacional uma vez que estas obras já se encontram protegidas a nível nacional. Objetou-se ainda que normas internacionais poderiam entravar a livre circulação de idéias e instituir, assim, um tipo de censura. Foi também mencionado que muitas obras literárias são conhecidas sobretudo por suas versões resumidas ou pela publicação de extratos. Para a preservação da integridade de tais obras foi sugerido o depósito, em bibliotecas ou instituições congêneres, de exemplar da edição original. O depósito legal pode ser considerado como medida eficaz para preservar a autenticidade da obra, pois permite a comparação entre o original e as obras derivadas.

Analisa os resultados da reunião do Comitê no contexto de todo o programa relativo ao Direito do Autor, que aborda, entre outros, os seguintes temas:

I - «aplicação e extensão do campo de aplicação geográfica dos instrumentos internacionais - sobre o Direito do Autor e sobre a proteção dos artistas intérpretes ou executantes, dos produtores de fonogramas e dos organismos de radiodifusão - adotados sob o patrocínio da UNESCO»;

II - «promoção do acesso às obras protegidas e estímulo à formulação de políticas nacionais sobre a proteção dos direitos do autor»;

III - «afirmação mais clara do papel e da função do direito de Autor como fator de promoção da educação da ciência e da cultura»;

IV - «elaboração de normas destinadas a reger as modalidades de aplicação do direito do Autor face à evolução das técnicas de criação, de difusão e ao estabelecimento de uma nova ordem econômica internacional». 
A partir deste último foi aceita a emenda proposta pelo Brasil ao Projeto de Programa e Orçamento durante a $21^{\mathrm{a}}$ Conferência Geral (Belgrado, 1980).

Parece, portanto, coerente que o Brasil assuma uma postura favorável ao desenvolvimento do projeto, que visa "ao estudo das medidas que deverão ser adotadas para preparar o terreno e determinar o modo de evitar a deturpação das obras de domínio público».

É preciso, porém, considerar a diversidade de interesses envolvidos, especialmente os comerciais. Boa parte dos países ocidentais não se deverá mostrar favorável à adoção de quaisquer medidas que possam limitar a livre circulação das obras do espírito, já que nestes países a «indústria e o comércio da cultura» assumem proporções consideráveis. Assim sendo parece que a posição do Brasil deveria se basear nos objetivos do programa de apoio de Plano a Prazo Médio:

$$
\begin{aligned}
& \text { I - proteger, conservar e valorizar a cultura nacional; } \\
& \text { II - } \text { buscar uma adaptação das normas tradicionais consideran- } \\
& \text { do as mudanças tecnológicas recentemente introduzidas; } \\
& \text { III - } \text { regulamentar as relações internacionais no que concerne à } \\
& \text { criação, produção, difusão e proteção das obras inte- } \\
& \text { lectuais. }
\end{aligned}
$$

O Brasil poderia, portanto, favorecer a adoção de regulamentação internacional sobre a proteção das obras caídas em domínio público, considerando tratar-se de texto a ser baseado nos direitos e deveres do cidadão e que possa ser incluído nas normas que regulam a propriedade intelectual. Da flexibilidade do texto dependerá a adesão de Estados como o Reino Unido, a Ãustria e os Países Baixos que, durante os trabalhos do Comitê, se manifestaram em oposição a qualquer norma internacional sobre a matéria. 